\title{
VOLVOX GLOBATOR.
}

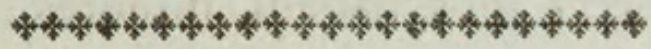

CHARACTER GENERICUS.

Vermis inconfpicuus, fimpliciffimus, pellucidus, fphæricus.

$$
\text { Müll. anim. infus. p. } 12 .
$$

CHARACTER SPECIFICUS, E̊c.

VOLVOX fphæricus membranaceus globulis fparfis.

Müll. anim infus. p. 18. t. 3. f. 12. 13. VOLVOX fphæricus membranaceus.

$$
\text { Lin. Syft. Nat. Gmel. p. } 3906 .
$$

VOLVOX globofus.

$$
\text { Lin. Syft. Nat. ed. } 12 .
$$

VOLVOX globofus immutabilis foetubus fparfis.

$$
\text { Pall. el. zooph. p. } 4 \mathrm{I} 7 \text {. }
$$

E maximis eft animalculis Volvox Globator qua microfcopii ope folent examinari, non raro etiam ipfo oculo evidenter videndus; globulo fimillimus flavo admodum feu aurantio, interdum viridi. Aquas ftagnantes, in quibus ut plurimum copiofe generatur, æftivo tempore fuis manifefte tingit coloribus. Movet fe inæqualiter et quaquaverfum, volutus veluti circa fuum axim. Si microfcopice examinetur, patebit 
patebit miro naturæ confilio continere fere femper hoc animalculum pullos matri fimiles, qui et ipfi penitius infpecti fuos habent minores; adeo ut in Volvoce Giobatore revera includi dicantur " nati natorum et qui nafcentur ab illis." 


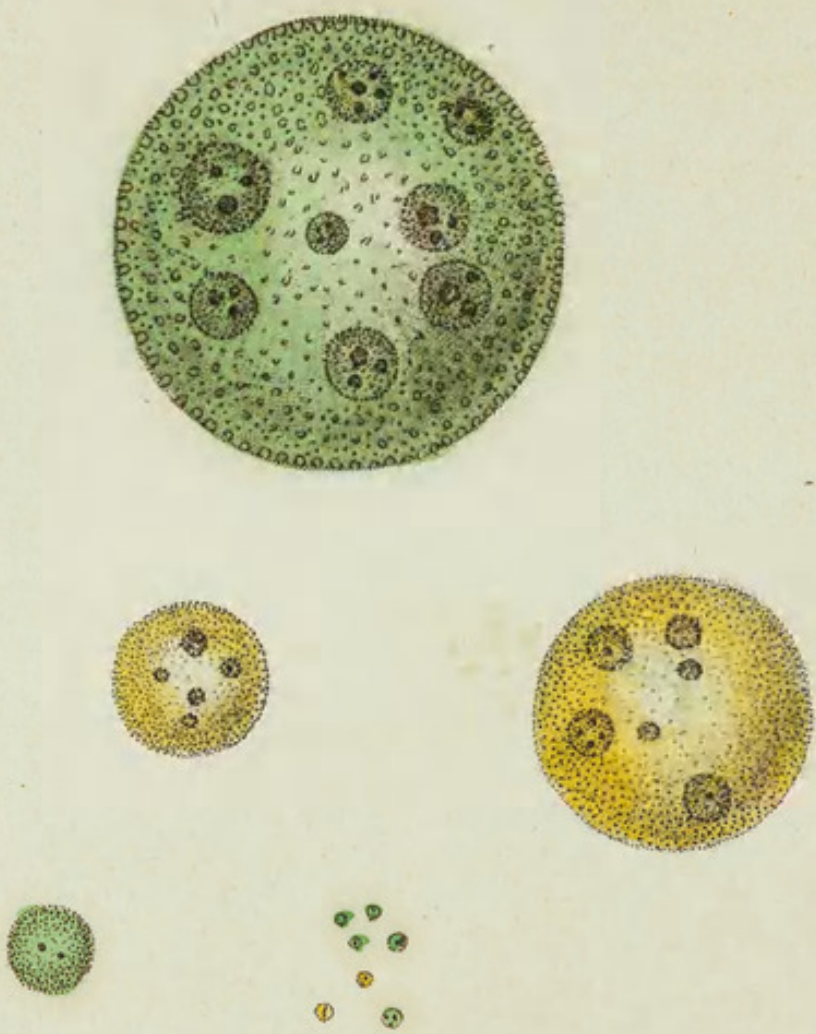

(6)

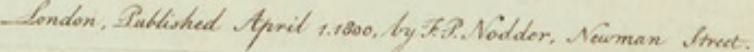




\section{THE \\ COMMON GLOBE-ANIMAL.}

$0 * * * * * 4 * * * * * * * * * * * * * 0$

GENERIC CHARACTER.

Animalcule fimple, fpherical, pellucid.

SPECIFIC CHARACTER, E̊C.

Spherical VOLVOX, either green or yellow, with varioufly-fized fcattered globulets.

The GLOBATOR.

The GLOBE-ANIMAL.

Baker Empl. for Micr.p. 322. pl. 12. f. 27.

Kugel-Thier.

Roes. ins. 3. p. 6r 7. pl. 101. f. I. $2.3^{\circ}$

The Volvox Globator or Globe-Animal is among the largeft of the microfcopic animalcules, and frequently arrives at fuch a fize as to be diftinctly vifible to the naked eye; appearing under the form of a fmall globule, fometimes of a deep yellow, or orange-color, and fometimes green. During the fummer months, fo numerous is this fpecies as to caufe a very vifible difcoloration of the fluid in which it is found. Its general refidence is in ftagnant $\mathrm{wa}_{\boldsymbol{*}}$ ters, Its motions are irregular, moving in all directions, 
rections, and at the fame time rolling or fpinning as if on an axis. When microfcopically examined, it exhibits one of the moft curious phenomena in natural hiftofy; being almoft always found pregnant with feveral fmaller and perfectly fimilar animalcules; and thefe if more clofely examined, will be found provided with a fill fmaller progeny; fo that the Globe-Animal contains within itfelf a tribe of already impregnated defcendants. 


\section{$2 \mathrm{BHL}$ Biodiversity Heritage Library}

Shaw, George. 1800. "The Common Globe-Animal, Volvox globator [PI. 427]." The Naturalist's Miscellany 11(CXXIX), https://doi.org/10.5962/p.310874.

View This Item Online: https://www.biodiversitylibrary.org/item/276496

DOI: https://doi.org/10.5962/p.310874

Permalink: https://www.biodiversitylibrary.org/partpdf/310874

\section{Holding Institution}

Museums Victoria

\section{Sponsored by}

Atlas of Living Australia

\section{Copyright \& Reuse}

Copyright Status: Public domain. The BHL considers that this work is no longer under copyright protection.

This document was created from content at the Biodiversity Heritage Library, the world's largest open access digital library for biodiversity literature and archives. Visit BHL at https://www.biodiversitylibrary.org. 